\title{
AMS RADIOCARBON DATING OF GIANT ROCK SCALLOP (HINNITES MULTIRUGOSUS) ARTIFACTS FROM SAN MIGUEL ISLAND, CALIFORNIA, USA
}

\author{
Todd J Braje ${ }^{1}$ - Torben C Rick ${ }^{2}$ Jon M Erlandson ${ }^{3}$
}

ABSTRACT. For at least $100,000 \mathrm{yr}$, marine shell beads have been important ornamental and symbolic artifacts intimately associated with the behavior of anatomically modern humans. In California, giant rock scallop (Hinnites multirugosus) beads were once thought to have been used only for the last $1000 \mathrm{yr}$, where they were considered to be markers of high social status among the Chumash Indians of the Santa Barbara Channel region. Direct accelerator mass spectrometry (AMS) radiocarbon dating of 1 giant rock scallop ornament and 2 beads from San Miguel Island extends the use of this shell for personal adornment to at least $8000 \mathrm{cal} \mathrm{BP}$. Our study emphasizes the importance of direct $\mathrm{AMS}{ }^{14} \mathrm{C}$ dating of artifacts to enhance cultural chronologies and clarify the antiquity of various technologies and associated behaviors. Our results also caution archaeologists when equating artifact rarity with sociopolitical complexity.

\section{INTRODUCTION}

Beads and other shell ornaments are widely regarded as hallmarks of modern human behavior, representing important symbolic aspects of art and culture. The earliest recognized marine shell beads in the world come from Middle Stone Age levels at Grotte de Pigeons in Morocco, Skhul in Israel, and Blombos Cave in South Africa, and consist of perforated tick shells (Nassarius spp.) dated between about 100,000 and 75,000 yr ago (Henshilwood et al. 2004; d'Errico et al. 2005; Vanhaeren et al. 2006; Bouzouggar et al. 2007). In Australia, shell beads from Mandu Mandu Rockshelter have been dated to 34,000 yr ago (Morse 1993), and in the New World, beads made from purple olive snails (Olivella biplicata) from southern California are among the oldest shell beads in the Americas, directly dated to about 11,000-9000 cal BP (see Erlandson et al. 2005a,b; Fitzgerald et al. 2005).

In California, shell beads and ornaments have long been important cultural historical time markers for archaeologists (e.g. King 1990). Prior to the advent of absolute dating techniques, shell bead typologies provided useful chronological indicators of cultural evolution, especially in coastal areas. Typological sequences of shell beads and other technologies associated with burials allowed early archaeologists to develop sophisticated culture historical sequences, many of which remain viable today (see Trigger 2006).

Shell bead typologies have been an especially fruitful avenue of study in southern California, where early Spanish chronicles and archaeological data documented formal shell bead currency and exchange networks extending throughout the Santa Barbara Channel area (Figure 1) and into distant interior regions. At first European contact, the Chumash manufactured and traded a diverse range of beads and ornaments made from Olivella, red and black abalone (Haliotis rufescens, $\mathrm{H}$. cracherodii), California mussel (Mytilus californianus), clam (Tivela stultorum), and other shells. A seminal study of shell bead typology and evolution was conducted by Chester King (1990), who relied on the seriation of shell beads and ornaments (and other artifacts) from burial lots to explore changes in Chumash society spanning $8000 \mathrm{yr}$.

\footnotetext{
${ }^{1}$ Department of Anthropology, Humboldt State University, Arcata, California 95521, USA. Corresponding author. Email: tjb50@ humboldt.edu.

${ }^{2}$ National Museum of Natural History, Smithsonian Institution, Department of Anthropology, Washington DC 20013-7012, USA.

${ }^{3}$ Department of Anthropology, University of Oregon, Eugene, Oregon 97403-1218, USA. Also: Museum of Natural and Cultural History, University of Oregon, Eugene, Oregon 97403-1224, USA.
} 


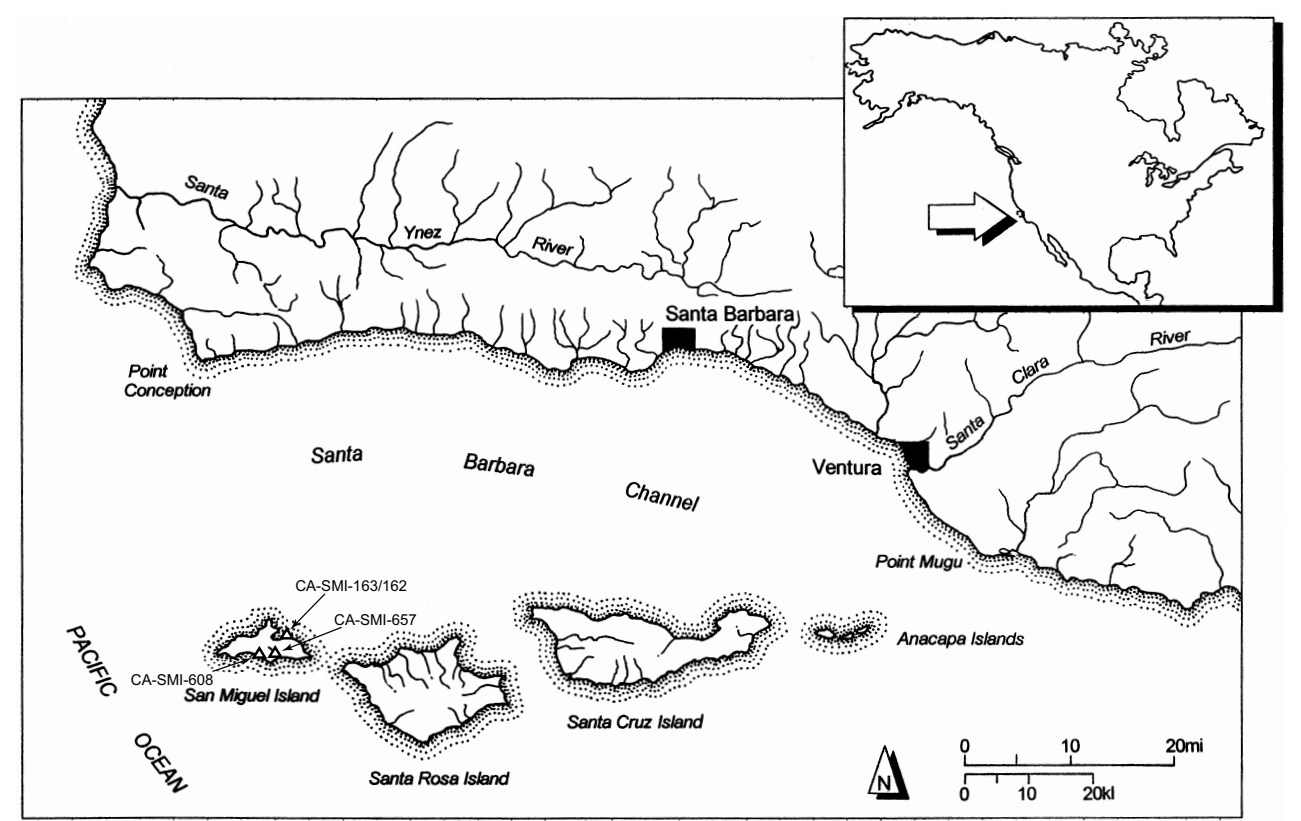

Figure 1 Map of the Santa Barbara Channel, San Miguel Island, and the sites discussed in the text

New discoveries, dates, and calibration methods have refined King's (1990) original shell bead chronology (see Kennett 2005), but his general sequence has sustained nearly $20 \mathrm{yr}$ of archaeological testing, improved dating and excavation techniques, and intellectual scrutiny. Archaeologists in recent years, however, have extended the antiquity of many of the shell bead and ornament types defined by Gifford (1947), Bennyhoff and Hughes (1987), King (1990), Gibson (1975, 1992), and others. These studies have demonstrated considerable continuity in the types of shells used to make beads and ornaments through time, while recognizing the dynamic nature of their invention, production, and sociopolitical significance (see Rick et al. 2005).

In this paper, we present the first AMS dates on relatively rare rock scallop (Hinnites multigosus) beads and ornaments recovered from recent excavations on San Miguel Island, the westernmost of the Northern Channel Islands. We provide contextual and chronological information for 3 Hinnites artifacts, extending the antiquity of these objects by 7000 yr. Hinnites beads, previously believed to have been used for only the past 1000 yr or so (King 1990:193), were thought to signify high social status among the Chumash Indians and their neighbors. Our considerably longer chronology provides a cautionary tale about equating artifact scarcity with the emergence of cultural complexity.

\section{CONTEXT AND BACKGROUND}

Today, San Miguel Island lies approximately $42 \mathrm{~km}$ off the Santa Barbara coast, but during the last glacial it formed the western end of a larger Santarosae Island (Orr 1968; Junger and Johnson 1980). The $37-\mathrm{km}^{2}$ island currently contains rolling hills, shifting dune sheets, tablelands, and marine terraces, with a Mediterranean climate and relatively impoverished terrestrial flora and fauna (Schoenherr et al. 1999). However, strong deep-water upwelling and extensive kelp forests support diverse and productive populations of shellfish, sea mammals, fishes, and seabirds, resources that attracted humans to the island for at least $11,000{ }^{14} \mathrm{C} \mathrm{yr}$. 
Historically, the Northern Channel Islands and the adjacent mainland coast were occupied by the Chumash Indians, complex maritime hunter-gatherers who subsisted primarily off marine resources. The Chumash lived in large villages and towns led by hereditary chiefs and had extensive craft-specialization and trade networks. Goods and services were regularly exchanged between the islands, the mainland, and interior with shell "money beads" manufactured from the enamel (callus) portion of the Olivella shell, which served as a medium of exchange (King 1990; Arnold 1991, 1992, 2000, 2001; Kennett 2005; Rick et al. 2005; Rick 2007).

A number of other decorative shell bead and ornament types were also produced by the Chumash, including those created from Olivella, red and black abalone, Pismo clam, California mussel, Kellet's whelk (Kelletia kelleti), cone shells (Conus californica), cowries (Cypraea spadicea), coffee bean shells (Trivia californiana), limpets (Megathura crenulata), and others (King 1990; Arnold and Graesch 2001:71). While several types of Olivella shell beads are relatively abundant in Late Holocene sites ( $<3500 \mathrm{cal} \mathrm{BP})$, some archaeologists have interpreted the recovery of less common shell bead types as symbols of high status and wealth reserved for elite members of society (see King 1990). This is especially true for beads and ornaments manufactured from giant rock scallop shells, a subtidal bivalve that has bright purple or reddish-purple sections of shell located near each hinge. King (1990:193) identified rock scallop beads as important time markers for the rise of cultural complexity in the Santa Barbara Channel, for example, due to their late appearance and scarcity in the archaeological record.

Our excavations and direct dating of Hinnites artifacts from 3 San Miguel Island sites, however, provide new insights into the antiquity of giant rock scallop beads and ornaments. Our results speak not only to the antiquity and cultural continuity of personal ornamentation along the Santa Barbara Channel and broader Pacific coast, but also the utility of direct shell artifact dating (see Vellanoweth 2001; Rick et al. 2002; Erlandson et al. 2005a,b; Fitzgerald et al. 2005).

\section{METHODS}

Three complete Hinnites artifacts were directly dated for our study. These artifacts were recovered from 3 San Miguel Island shell middens (CA-SMI-162, CA-SMI-608, and CA-SMI-657) previously dated to the Early, Middle, and Late Holocene. Each Hinnites artifact was cleaned, etched twice in dilute hydrochloric acid, and rinsed in distilled water to remove any contaminants. The artifacts were then sampled with a dental drill across multiple shell growth increments to average out annual variations in upwelling and the marine reservoir effect (Culleton et al. 2006). A powdered sample from each specimen was sent to the National Ocean Sciences AMS (NOSAMS, http:// www.nosams.whoi.edu/nosams.html) facility at Woods Hole Oceanographic Institute (WHOI) for analysis. Specimens were converted to $\mathrm{CO}_{2}$ by reaction with $85 \%$ phosphoric acid under vacuum and converted to graphite.

All dates were calibrated with CALIB 5.0.2 (Stuiver and Reimer 1993; Stuiver et al. 2000, 2005), applying a $\Delta \mathrm{R}$ of $225 \pm 35 \mathrm{yr}$ to the reservoir correction, which is an average commonly used in the region (see Kennett et al. 1997). Radiocarbon dating of shell and charcoal pairs of 2 trans-Holocene sites on San Miguel Island, Daisy Cave and Cave of the Chimneys, demonstrated that $\Delta \mathrm{R}$ values fluctuated somewhat through the Holocene, including a highly variable interval between 9470 and 8910 BP (Erlandson et al. 1996; Kennett et al. 1997:1058). Kennett et al. (1997:1055) concluded that $\Delta \mathrm{R}$ values were relatively stable during our study interval and that the $225 \pm 35 \mathrm{yr}$ reservoir correction is adequate for time intervals outside of 9470-8910 cal BP and 3560-3460 cal BP. Rick et al. (2002:936) also noted that using different $\Delta \mathrm{R}$ values reported for the area (e.g. $233 \pm 60 \mathrm{yr}$ 
[Ingram and Southon 1996]; $210 \pm 80 \mathrm{yr}$ [Kennett et al. 1997]) affected the overall calibrated age of a sample by a relatively small margin (e.g. $<100 \mathrm{yr}$ ).

\section{SITE AND SAMPLE DESCRIPTIONS}

\section{CA-SMI-608}

This large eroding shell midden is exposed in a south coast gully system with intact site deposits extending for at least $50 \mathrm{~m}$ north-south and $80 \mathrm{~m}$ east-west. The shell midden ranges from 10 to $40 \mathrm{~cm}$ thick and formed in a well-developed paleosol buried 1.5-2.0 m below the surface. Braje and Erlandson conducted surface collections from eroding deposits and excavated approximately $600 \mathrm{~L}$ of intact sediments, which produced a variety of faunal remains and artifacts made from stone, bone, and shell (Erlandson et al. 2005a; Braje 2007). Four ${ }^{14} \mathrm{C}$ dates were submitted from the main site area, documenting an Early Holocene occupation between about 9700 and 8500 cal BP (Table 1).

Table $1{ }^{14} \mathrm{C}$ dates from CA-SMI-163, CA-SMI-657, and CA-SMI-608. ${ }^{\mathrm{a}}$

\begin{tabular}{|c|c|c|c|c|c|c|c|}
\hline $\begin{array}{l}\text { Site \# } \\
\text { (CA-SMI-) }\end{array}$ & Material $^{\mathrm{b}}$ & Lab \# & Provenience & $\begin{array}{l}\text { Measured } \\
{ }^{14} \mathrm{C} \text { age }\end{array}$ & $\begin{array}{l}\text { Conventional } \\
{ }^{14} \mathrm{C} \text { age }\end{array}$ & $\begin{array}{l}\text { Age range } \\
(\text { cal } \mathrm{BP}, 1 \sigma)\end{array}$ & Source \\
\hline 163 & $\mathrm{Hc}$ & OS-27183 & Top of Unit 2, H5 & $\mathrm{n} / \mathrm{a}$ & $655 \pm 60$ & - & Rick 2007 \\
\hline 163 & $\mathrm{Mc}$ & Beta-145428 & $\mathrm{H} 1,25 \mathrm{~cm}$ & $330 \pm 60$ & $760 \pm 60$ & $260-80$ & Rick 2007 \\
\hline 163 & $\mathrm{Mc}$ & OS-33376 & $\mathrm{H} 3$, Auger C, $43 \mathrm{~cm}$ & $\mathrm{n} / \mathrm{a}$ & $830 \pm 25$ & $300-150$ & Rick 2007 \\
\hline 163 & $\mathrm{Mc}$ & OS-33375 & H6, Auger D, $64 \mathrm{~cm}$ & $\mathrm{n} / \mathrm{a}$ & $880 \pm 35$ & $370-260$ & Rick 2007 \\
\hline 163 & $\mathrm{Mc}$ & OS-33417 & Unit $2, \sim 110 \mathrm{~cm}$ & $\mathrm{n} / \mathrm{a}$ & $880=$ & $360-260$ & Rick 2007 \\
\hline 163 & $\mathrm{Mc}$ & OS-33377 & $\mathrm{H} 2$, Auger B, $29 \mathrm{~cm}$ & $\mathrm{n} / \mathrm{a}$ & $885 \pm 35$ & $370-260$ & Rick 2007 \\
\hline 163 & $\mathrm{Hc}$ & Beta-138430 & $\mathrm{H} 5$, Auger 3, $67 \mathrm{~cm}$ & $510 \pm 70$ & $950 \pm 70$ & $440-295$ & Rick 2007 \\
\hline 163 & $\mathrm{Mc}$ & OS-37142 & Auger $2, \sim 40 \mathrm{~cm}$ & $\mathrm{n} / \mathrm{a}$ & $955 \pm 50$ & 430 & Rick 2007 \\
\hline 163 & Charcoal & CAMS-14365 & $\mathrm{H} 4$, probe, $10 \mathrm{~cm}$ & $310 \pm 60$ & $310 \pm 60$ & 455 & Rick 2007 \\
\hline 163 & $H r$ BIP & OS-34803 & Unit $2,70-80 \mathrm{~cm}$ & $\mathrm{n} / \mathrm{a}$ & $1010 \pm 40$ & $480-370$ & Rick 2007 \\
\hline 163 & $\mathrm{Mc}$ & OS-34805 & Unit $3,27-28 \mathrm{~cm}$ & $\mathrm{n} / \mathrm{a}$ & $1060 \pm 35$ & $510-430$ & Rick 2007 \\
\hline 163 & $H r \mathrm{~B}$ & OS-34802 & Unit $2,10-20 \mathrm{~cm}$ & $\mathrm{n} / \mathrm{a}$ & $1320 \pm 30$ & $700-620$ & Rick 2007 \\
\hline 163 & $\mathrm{Mc}$ & OS-3 & Unit 3 & $\mathrm{n} / \mathrm{a}$ & 1790 & $1170-1060$ & Rick 2007 \\
\hline 163 & $\mathrm{Mc}$ & OS-33420 & Duplicate OS-33374 & $\mathrm{n} / \mathrm{a}$ & $1930 \pm 30$ & $1305-1220$ & Rick 2007 \\
\hline 657 & $\mathrm{Hr}$ & Beta-217110 & Bulk Sample 1 & $5460 \pm 90$ & $5900 \pm 90$ & $6190-5970$ & Braje 2007 \\
\hline 657 & Ms & Beta-195745 & South Locus & $6240 \pm 80$ & $6670 \pm 80$ & $7060-6820$ & Braje 2007 \\
\hline 608 & $\mathrm{Mc}$ & Beta-180771 & SE site area & $8020 \pm 80$ & $8430 \pm 80$ & $8860-8590$ & Braje 2007 \\
\hline 608 & $\mathrm{Mc}$ & OS-44638 & Bulk Sample 1 & $\mathrm{n} / \mathrm{a}$ & $9200 \pm 50$ & $9720-9540$ & Braje 2007 \\
\hline 608 & $\mathrm{Hc}$ & & & $8650 \pm 60$ & $9060 \pm 60$ & $9550-9425$ & Braje 2007 \\
\hline 608 & $\mathrm{Ol}$ & OS-48347 & Bulk Sample 2 & $\mathrm{n} / \mathrm{a}$ & $9070 \pm 45$ & $9540-9450$ & Braje 2007 \\
\hline
\end{tabular}

${ }^{\mathrm{a} C o m p i l e d ~ f r o m ~ B r a j e ~(2007) ~ a n d ~ R i c k ~(2007) . ~}$

${ }^{\mathrm{b}} \mathrm{Hc}=$ Haliotis cracherodii, $\mathrm{Hr}=$ Haliotis rufescens, $\mathrm{Mc}=$ Mytilus californianus, $\mathrm{Ol}=$ Olivella bead, $\mathrm{Ms}=$ Marine shell, $\mathrm{BIP}=$ bead in production.

A single giant rock scallop ornament was recovered from the site surface, eroding from the dark midden soil (Figure 2). This ornament is from a water-rolled hinge portion of a rock scallop shell. A naturally eroded hole is present at the end opposite the hinge, and the interior edges of the body portion were ground, shaped, and flattened. This Hinnites ornament, probably a pendant, is a maximum of $41.6 \mathrm{~mm}$ long and $32.8 \mathrm{~mm}$ wide.

\section{CA-SMI-657}

Located on the south-central coast, CA-SMI-657 consists of 3 shell midden loci exposed in the walls of a large gully. Each locus is buried beneath between 1-2 $\mathrm{m}$ of historic dune sand, with the midden 


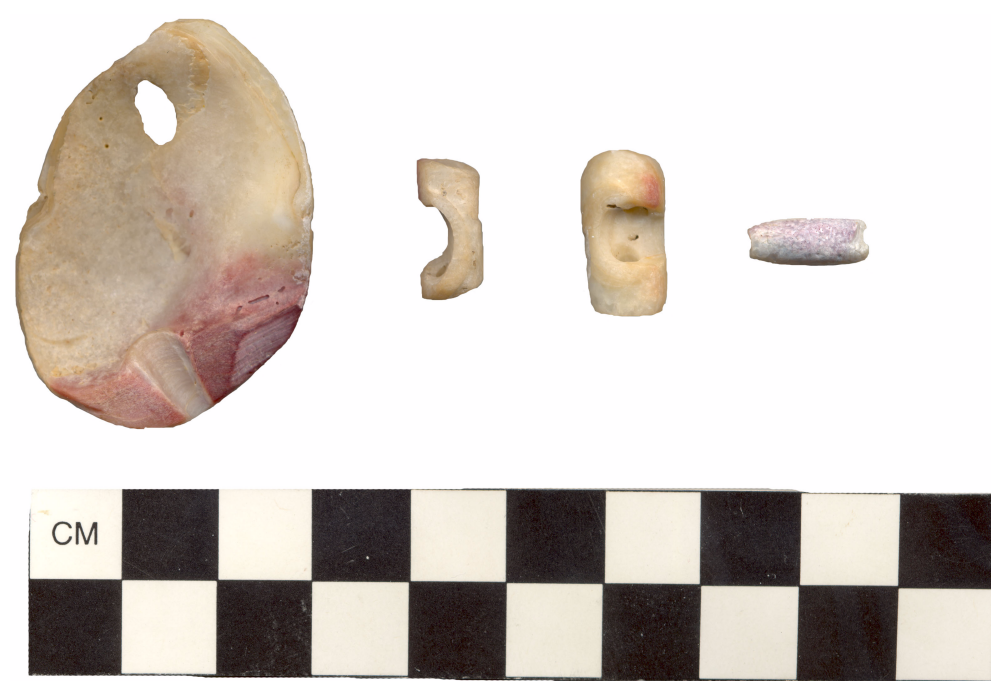

Figure 2 Giant rock scallop ornaments and beads from CA-SMI-608, CA-SMI-657 $(n=2)$, and CA-SMI-162 (left to right).

dominated by large red abalone shells in a yellow-tan alluvial paleosol. Braje (2007) obtained ${ }^{14} \mathrm{C}$ samples from the midden exposures (Table 1) and excavated a 100-L bulk sample and a $2 \times 1 \mathrm{~m}$ test unit in the eastern gully wall of the northernmost locus.

While the midden constituents were dominated by rocky intertidal shellfish and the artifact densities were relatively low (see Braje 2007), 2 unusual rock scallop beads were recovered from the test unit. These beads were made from the brightly colored hinge portion of the shell. The tube-shaped beads show remnant dark red to deep purple coloring at one end where the hinge was ground into a smooth tube shape. One lateral side of each bead was drilled and carved out, leaving a C-shaped indentation. Both ends of the beads were then drilled from the exterior to the interior, probably to allow the beads to be strung. It is also possible, however, that these colorful shell ornaments were used as sliding choker clasps on a draw string or necklace.

\section{CA-SMI-162 and CA-SMI-163}

This large Chumash village complex, located in the Cuyler Harbor area, contains several house depressions and dense midden deposits that appear to be over $2 \mathrm{~m}$ thick in places. Rick (2007) excavated CA-SMI-163 and reported large and diverse artifact assemblages, including Olivella and red abalone shell beads, and dense invertebrate and vertebrate faunal remains. Adjacent to CA-SMI-163 is CA-SMI-162, which contains midden deposits and a cemetery. Beads noted on the site surface included Olivella callus cup beads and red abalone disk beads, which suggest a similar antiquity as the adjacent village complex at CA-SMI-163. A Hinnites tube bead was recovered from the surface of CA-SMI-162. No Hinnites artifacts were identified at CA-SMI-163.

Before our study, no ${ }^{14} \mathrm{C}$ dates were available from CA-SMI-162. At adjacent CA-SMI-163, however, Rick (2007) obtained $14{ }^{14} \mathrm{C}$ dates, including samples from 2 excavation units, several auger holes, and other exposures around the site. These dates suggest that CA-SMI-163 was primarily occupied from about 500-150 cal BP with an ephemeral component dated to around $1200 \mathrm{cal}$ BP. Artifacts recovered from CA-SMI-163 and CA-SMI-162 are consistent with this chronology. 


\section{RESULTS}

AMS analysis of the Hinnites artifacts produced a range of ${ }^{14} \mathrm{C}$ dates spanning over $7000 \mathrm{yr}$. The ornament from CA-SMI-608 produced a conventional ${ }^{14} \mathrm{C}$ age of $7970 \pm 45 \mathrm{BP}$. Calibration of this date yielded a 1- $\sigma$ age range of 8290-8160 cal BP (Table 2), corresponding to the younger range of several Early Holocene dates from nearby midden deposits (see Braje et al. 2004; Erlandson et al. 2005a; Braje 2007). The dating of this Hinnites pendant adds to the relatively narrow range of ornamental shell artifacts known to have been used along the California coast during the Early Holocene (see Erlandson 1994). Direct dating of one of the Hinnites beads from CA-SMI-657 produced a conventional ${ }^{14} \mathrm{C}$ age of $5920 \pm 40 \mathrm{BP}$ and a calibrated age range of 6180-6020 cal BP. A fragment of well-preserved and unmodified marine shell (food refuse) from the northern locus was also submitted for ${ }^{14} \mathrm{C}$ dating, yielding a calibrated age range of 6190-5970 cal BP, a date that overlaps with the direct date on the Hinnites bead. Finally, direct dating of the Hinnites tube bead from CA-SMI-162 yielded a conventional ${ }^{14} \mathrm{C}$ age of $980 \pm 30$ and calibrated age range of $450-330 \mathrm{cal} \mathrm{BP}$. This date correlates well with the other $14{ }^{14} \mathrm{C}$ dates from adjacent CA-SMI-163 that bracket the occupation of this large site complex between about 1290 and 150 cal BP (Rick 2007).

Table $2{ }^{14} \mathrm{C}$ dates from directly dated giant rock scallop artifacts from San Miguel Island.

\begin{tabular}{llllll}
\hline $\begin{array}{l}\text { Site \# } \\
(\text { CA-SMI-) }\end{array}$ & Lab \# & Provenience & $\begin{array}{l}\text { Measured } \\
{ }^{14} \mathrm{C} \text { age }\end{array}$ & $\begin{array}{l}\text { Conventional } \\
{ }^{14} \mathrm{C} \text { age }\end{array}$ & $\begin{array}{l}\text { Age range } \\
(\text { cal BP, 1 } \sigma)\end{array}$ \\
\hline 608 & OS-57715 & $10 \mathrm{~m}$ NE of Unit 2 & $\mathrm{n} / \mathrm{a}$ & $7970 \pm 45$ & $8290-8160$ \\
657 & OS-56706 & Unit 1, level 2 & n/a & $5920 \pm 40$ & $6180-6020$ \\
162 & OS-59486 & Surface & n/a & $980 \pm 30$ & $450-330$ \\
\hline
\end{tabular}

\section{DISCUSSION}

Giant rock scallop tube or globular beads and ornaments have been previously identified by Gifford (1947:45-46), Harrington (1928:160-162), King (1990:192-193), and others from coastal archaeological sites located on the southern California mainland and offshore islands. In an early Smithsonian publication, Holmes (1883:225-227) illustrated and described 2 Hinnites beads and 1 bead preform from San Miguel Island and the mainland village complex of Dos Pueblos, beads very similar to the CA-SMI-657 specimens. Later, Harrington (1928:160-162) also identified giant rock scallop beads, describing 74 drilled tube beads from burial contexts found at CA-SBA- 28 on the Santa Barbara mainland. Gifford (1947:46) studied an ethnographic collection of tube beads and concluded that they usually were found with a variety of other bead types and probably strung together for highly ranked individuals.

The most common Hinnites bead types are cylinder, tube, or globular forms from Late period (about AD 1300-1800) sites, constructed from the brightly colored hinge portion of the shell (King 1990: 192). King (1990:192-193) concluded that tube and globular varieties, similar to the CA-SMI-162 specimen, were only made during Late period phases L2 and L3 (about AD 1500-1800) and most were manufactured on the Northern Channel Islands with examples rarely found outside the Santa Barbara Channel region. It is interesting to note that this later use of purple or red Hinnites beads corresponds to the Protohistoric and Historic periods following first European contacts with the Chumash, a period when colorful glass beads traded to California Indians may have stimulated the production of greater numbers of brightly colored beads. While no description is provided, King (1990:240-241) illustrated 2 beads similar to the CA-SMI-657 specimens-a tube bead with both ends drilled and a C-shaped indentation carved out from the middle. King (1990) also attributed these to his Late period phases L2 and L3, some 4500 yr younger than the directly dated beads from 
our excavations at CA-SMI-657. Holmes' (1883) Dos Pueblos site contains a component of comparable antiquity to CA-SMI-657, but the lack of provenience makes it impossible to determine the age of those beads without direct dating.

Based on the restricted distribution of Hinnites tube beads in cemeteries and their association with other rare or "exclusive" types, King (1990:193) concluded that their use "apparently reflects the growth of complexity of the Chumash economy and of the political system." The recovery of these giant rock scallop beads and ornaments from Early and Middle Holocene shell middens, well before the documented appearance of sociopolitical complexity in Late Holocene southern California (Kennett 2005; Rick et al. 2005), is intriguing. These data suggest that giant rock scallop shells were used as raw materials in the manufacture of ornaments and beads for at least $8000 \mathrm{yr}$, a testament to their long history as important ornamental, social, and cultural symbols for the Chumash and their ancestors.

Giant rock scallops in southern California inhabit subtidal environments and the dense hinge portions of their shells are difficult to modify, shape, and drill. The energy investment required to collect these shellfish and create beads and ornaments from their shells (especially since black abalone, California mussel, and Olivella shells are more widely available and easier to modify) may have prevented widespread production. Their rarity in the archaeological record may reflect the increased labor investment required to collect and process them. While they appear to have been produced more regularly during the Late Holocene when populations grew, sociopolitical hierarchies emerged, and craft production increased, the presence of cylinder, tube, or globular Hinnites beads do not necessarily signal the emergence of elites or cultural complexity in the Santa Barbara Channel region. Although specific types of Hinnites beads or ornaments may still serve as good chronological markers, more direct dating of these and other artifacts is required to document such technological and artistic changes.

Our research has shown that Hinnites ornaments developed at least $7000 \mathrm{yr}$ earlier than previously thought. Further excavations, direct dating of artifacts, and the analysis of museum collections can help archaeologists determine both the antiquity and the meaning of ancient artifact types and classes. These studies can assist archaeologists in better understanding when and how personal ornamentation and artifact types change in cultural meaning, perhaps from expressions of beauty to those of wealth and social status. Although the relatively rare Hinnites beads may have served as status markers for the Chumash, their occasional presence in much earlier sites raises questions about such interpretations. Ultimately, the most significant aspect of this discovery may be as a cautionary tale of equating artifact rarity with social, political, or economic complexity.

\section{ACKNOWLEDGMENTS}

Our research was supported by a National Science Foundation grant (BCS-0613982, Braje and Erlandson), Channel Islands National Park, a Mia Tegner Memorial Grant (Erlandson and Braje) from the Marine Conservation Biology Institute, the Western National Parks Association, and the University of Oregon. At Channel Islands National Park, we thank Kelly Minas, Ann Huston, and Ian Williams for their continued support of our research. Erik Erlandson, Tracy Garcia, Dustin Kennedy, and Joel Wirtz helped during field work. Finally, we are indebted to Fiona Petchey, 2 anonymous reviewers, and Mark McClure and the editorial staff at Radiocarbon for assistance in the review, revision, and production of this paper. 


\section{REFERENCES}

Arnold JE. 1991. Transformation of a regional economy: sociopolitical evolution and the production of valuables in southern California. Antiquity 65(249):95362.

Arnold JE. 1992. Complex hunter-gatherer-fishers of prehistoric California: chiefs, specialists, and maritime adaptations of the Channel Islands. American Antiquity 57(1):60-84.

Arnold JE. 2000. The origins of hierarchy and the nature of hierarchical structures in prehistoric California. In: Diehl MW, editor. Hierarchies in Action: Cui Bono? Carbondale: Center for Archaeological Investigation, Southern Illinois University. p 221-40.

Arnold JE, editor. 2001. The Origins of a Pacific Coast Chiefdom: The Chumash of the Channel Islands. Salt Lake City: University of Utah Press. 317 p.

Arnold JE, Graesch AP. 2001. The evolution of specialized shellworking among the Island Chumash. In: Arnold JE, editor. The Origins of a Pacific Coast Chiefdom: The Chumash of the Channel Islands. Salt Lake City: University of Utah Press. p 71-112.

Bouzouggar A, Barton N, Vanhaeren M, d'Errico F, Collcutt S, Higham T, Hodge E, Parfitt S, Rhodes E, Schwenninger J-L, Stringer C, Turner E, Ward S, Moutmir A, Stambouli A. 2007. 82,000-year-old shell beads from north Africa and implications for the origins of modern human behavior. Proceedings of the National Academy of Sciences 104(24):9964-9.

Bennyhoff JA, Hughes RE. 1987. Shell Bead and Ornament Exchange Networks Between California and the Western Great Basin. Anthropological Papers Volume 64, Part 2. New York: American Museum of Natural History. $95 \mathrm{p}$.

Braje TJ. 2007. Archaeology, human impacts, and historical ecology on San Miguel Island, California [PhD dissertation]. Eugene: University of Oregon.

Braje TJ, Erlandson JM, Rick TC. 2004. An 8700 CALYBP shell midden from the south coast of San Miguel Island, California. Current Research in the Pleistocene 21:24-5.

Culleton BJ, Kennett DJ, Ingram BL, Erlandson JM, Southon JR. 2006. Intrashell radiocarbon variability in marine mollusks. Radiocarbon 48(3):387-400.

d'Errico F, Henshilwood C, Vanhaeren M, van Niekerk K. 2005. Nassarius kraussianus shell beads from Blombos Cave: evidence for symbolic behaviour in the Middle Stone Age. Journal of Human Evolution 48(1):3-24.

Erlandson JM. 1994. Early Hunter-Gatherers of the California Coast. New York: Plenum Press. 364 p.

Erlandson JM, Kennett DJ, Ingram BL, Guthrie DA, Morris DP, Tveskov T, West GJ, Walker PL. 1996. An archaeological and paleontological chronology for Daisy Cave (CA-SMI-261), San Miguel Island, California. Radiocarbon 38(2):355-73.

Erlandson JM, Braje TJ, Rick TC, Peterson J. 2005a.
Beads, bifaces, and boats: an early maritime adaptation on the south coast of San Miguel Island, California. American Anthropologist 107(4):677-83.

Erlandson JM, Macko ME, Koerper HC, Southon J. 2005b. The antiquity of Olivella shell beads at CAORA-64: AMS radiocarbon dated between 9420 and 7780 cal BP. Journal of Archaeological Science 32(3): 393-8.

Fitzgerald RT, Jones TL, Schroth A. 2005. Ancient longdistance trade in western North America: new AMS radiocarbon dates from southern California. Journal of Archaeological Science 32(3):423-34.

Gibson RO. 1975. The beads of Humaliwo. The Journal of California and Great Basin Anthropology 2(1): 110-9.

Gibson RO. 1992. An introduction to the study of aboriginal beads from California. Pacific Coast Archaeological Society Quarterly 28(3):1-45.

Gifford EW. 1947. Californian shell artifacts. University of California Anthropological Records 9(1):1-114.

Harrington JP. 1928. Exploration of the Burton mound at Santa Barbara, California. Annual Report of the Bureau of American Ethnology for the Years 1926-1927 44:23-168.

Henshilwood C, d'Errico F, Vanhaeren M, van Niekerk K, Jacobs Z. 2004. Middle Stone Age beads from South Africa. Science 304(5669):404.

Holmes WH. 1883. Art in shell of the ancient Americans. In: Powell JW, editor. Second Annual Report of the Bureau of Ethnology to the Secretary of the Smithsonian Institution. Washington, DC: Government Printing Office. p 185-305.

Ingram BL, Southon JR. 1996. Reservoir ages in eastern Pacific coastal and estuarine waters. Radiocarbon 38(3):573-82.

Junger A, Johnson DL. 1980. Was there a Quaternary land bridge to the Northern Channel Islands? In: Power DM, editor. The California Islands Symposium: Proceedings of a Multidisciplinary Symposium. Santa Barbara: Santa Barbara Museum of Natural History. p 33-9.

Kennett DJ. 2005. The Island Chumash: Behavioral Ecology of a Maritime Society. Berkeley: University of California Press. 320 p.

Kennett DJ, Ingram BL, Erlandson JM, Walker P. 1997. Evidence for temporal fluctuations in marine radiocarbon reservoir ages in the Santa Barbara Channel, southern California. Journal of Archaeological Science 24(11):1051-9.

King CD. 1990. The Evolution of Chumash Society: A Comparative Study of Artifacts Used for Social System Maintenance in the Santa Barbara Channel Region Before A.D. 1804. New York: Garland Publishing. $296 \mathrm{p}$.

Morse K. 1993. Shell beads from Mandu Mandu Creek Rock-shelter, Cape Range Peninsula, western Austra- 
lia, dated before 30,000 B.P. Antiquity 67(257):87783.

Orr PC. 1968. Prehistory of Santa Rosa Island. Santa Barbara: Santa Barbara Museum of Natural History. $253 \mathrm{p}$.

Rick TC. 2007. The Archaeology and Historical Ecology of Late Holocene San Miguel Island. Los Angeles: Cotsen Institute of Archaeology, UCLA. 180 p.

Rick TC, Vellanoweth RL, Erlandson JM, Kennett DJ. 2002. On the antiquity of the single-piece shell fishhook: AMS radiocarbon evidence from the southern California coast. Journal of Archaeological Science 29(9):933-42.

Rick TC, Erlandson JM, Vellanoweth RL, Braje TJ. 2005. From Pleistocene mariners to complex huntergatherers: the archaeology of the California Channel Islands. Journal of World Prehistory 19(3):169-228.

Schoenherr A, Feldmath CR, Emerson M. 1999. Natural History of the Islands of California. Berkeley: University of California Press.
Stuiver M, Reimer PJ. 1993. Extended ${ }^{14} \mathrm{C}$ data base and revised CALIB $3.0{ }^{14} \mathrm{C}$ age calibration program. $R a$ diocarbon 35(1):215-30.

Stuiver M, Reimer PJ, Reimer RW. 2000. CALIB 4.3 radiocarbon calibration program. [WWW program and documentation]. Seattle: University of Washington and Belfast: Queen's University Belfast. URL: http:// www.calib.org.

Stuiver M, Reimer PJ, Reimer RW. 2005. CALIB 5 manual [WWW document]. URL: http://calib.qub.ac.uk/ calib/manual/.

Trigger BG. 2006. A History of Archaeological Thought. New York: Cambridge University Press. 500 p.

Vanhaeren M, d'Errico F, Stringer C, James SL, Todd JA, Mienis HK. 2006. Middle Paleolithic shell beads in Israel and Algeria. Science 312(5781):1785-8.

Vellanoweth RL. 2001. AMS radiocarbon dating and shell bead chronologies: Middle Holocene exchange and interaction in western North America. Journal of Archaeological Science 28(9):941-50. 